\title{
VESUVIANITE FROM PAJSBERG, SWEDEN, AND THE ROLE OF Be IN THE VESUVIANITE STRUCTURE
}

\author{
SHARON FITZGERALD \\ University Museums, University of Delaware, Newark, Delaware 19716 U.S.A. \\ Peter B. LEAVENS ${ }^{\S}$ \\ Department of Geosciences, University of Delaware, Newark, Delaware 19716 U.S.A. \\ GEORGE R. ROSSMAN
}

Division of Geological and Planetary Sciences, California Institute of Technology, Pasadena, California 91125-2500 U.S.A.

GLENN P.A. YAP

Department of Chemistry and Biochemistry, University of Delaware, Newark Delaware 19716 U.S.A.

TIмотнY ROSE

Department of Mineral Sciences, Smithsonian Institution, PO Box 37012, MRC 119, Washington, DC 20013-7012 U.S.A.

\begin{abstract}
Vesuvianite from Pajsberg, Sweden contains about one atom of Mn, based on 50 cations per formula unit, and small amounts of $\mathrm{Be}, \mathrm{B}$, and As. Optical absorption analysis suggests that the Mn is predominantly or entirely trivalent. Crystalstructure analysis indicates that $\mathrm{Mn}$ is housed at the general octahedral site Y3, which exhibits only minor distortion from ideal octahedral symmetry. Arsenic is housed at Y2 and Z2, and the formula derived from electron microprobe and LA-ICP-MS analyses suggests minor substitution of $\mathrm{Al}$ for Si, also at Z2. Beryllium and B are at T1, between the edge-sharing trimers $\mathrm{Y} 3 \mathrm{Y} 2 \mathrm{Y} 3$, as is the case for B in the boron-dominant vesuvianite species wiluite. The total content at $\mathrm{T} 1$ is interpreted as $0.82 \mathrm{Be}$, $0.34 \mathrm{~B}$, and $0.037 \mathrm{Fe}^{3+}$.
\end{abstract}

Keywords: vesuvianite, optical spectra, crystal structure, Be As.

\section{INTRODUCTION}

Vesuvianite is one of the most chemically and structurally complex of the silicate minerals. The formula for most vesuvianites may be written as

$$
\begin{aligned}
& \mathrm{X} 1_{2} \mathrm{X} 2_{8} \mathrm{X} 3_{8} \mathrm{X} 4 \mathrm{Y} 1 \mathrm{Y} 2_{4} \mathrm{Y}_{3} \mathrm{~T}_{4}\left(\mathrm{SiO}_{4}\right)_{10}\left(\mathrm{Si}_{2} \mathrm{O}_{7}\right)_{4} \\
& \quad(\mathrm{O}, \mathrm{OH}, \mathrm{F})_{10}
\end{aligned}
$$

(Groat \& Hawthorne 1992), where the X sites are eight-coordinated, $\mathrm{Y}$ sites six or five-coordinated, and $\mathrm{Z}$ and $\mathrm{T}$ sites four coordinated; more compactly, it may be written as

$$
\mathrm{X}_{19} \mathrm{Y}_{13} \mathrm{~T}_{4} \mathrm{Si}_{18} \mathrm{O}_{68}(\mathrm{O}, \mathrm{OH}, \mathrm{F})_{10}
$$

where $\mathrm{X}=\mathrm{Ca}, \mathrm{Na}$, and REE, chiefly Ce (Fitzgerald et al. 1987); $\mathrm{Y} 1=\mathrm{Cu}^{2+}, \mathrm{Mn}^{3+}, \mathrm{Fe}^{3+}$, or $\mathrm{Al}$ (Rucklidge et al. 1975, Fitzgerald et al. 1986a, b, Armbruster et al. 2002); $\mathrm{Y} 2=\mathrm{Al} ; \mathrm{Y} 3=\mathrm{Al}, \mathrm{Fe}^{3+}, \mathrm{Fe}^{2+}, \mathrm{Mg}, \mathrm{Mn}^{2+}$, Ti, $\mathrm{Zn}$, with divalent cations ideally $=2$; and $\mathrm{T}$ being vacant, or occupied by B (Groat et al. 1994b), or small amounts of $\mathrm{Al}$ or other Y-group cations (Groat et al. 1994a). Additionally, vesuvianite may contain B, Cl,

$\S$ Corresponding author e-mail address: pbl@udel.edu 
or $\mathrm{Bi}$ at additional positions, and an additional oxygen atom (O12) to help charge-balance them (Groat et al. 1994b, Groat \& Evans 2012.)

The dark, brownish-red vesuvianite from Pajsberg, Sweden, has been anomalous since it was first analyzed by Flink (1887, reported in Dana 1893), who found $12.49 \% \mathrm{MnO}$. The analysis cannot be converted into a plausible vesuvianite formula; on the basis of $50 \mathrm{X}+\mathrm{Y}+\mathrm{Si}$ cations, $\mathrm{Ca}=15.74$ apfu (atoms per formula unit) instead of the expected 19 apfu, and $\mathrm{Si}=18.36$ apfu.

Fitzgerald et al. (1992) found only 2.92 and $2.41 \%$ $\mathrm{MnO}$ by microprobe analyses in two samples of Pajsberg vesuvianite, in line with vesuvianite from Franklin, New Jersey and other localities, and they were unable to create an entirely satisfactory empirical formula for the material. If the formulae are calculated on the basis of $50 \mathrm{X}+\mathrm{Y}+\mathrm{Si}$ cations, $\mathrm{Ca}+\mathrm{Na}$ are substantially below the ideal 19 apfu and $\mathrm{Si}$ even further below the ideal $18 \mathrm{apfu}$. These anomalies suggested that the Pajsberg vesuvianite contains excess Y-group cations (Groat et al. 1994a). If the formulae are calculated on the basis of $19 \mathrm{Ca}+\mathrm{Na}$, or full occupancy of the X-sites, $\mathrm{Si}$ is still below the expected $18 a p f u$, and Y-group cations are in excess of 13 apfu by about 1.5 . These uncertainties regarding the composition and crystal chemistry of the Pajsberg vesuvianite prompted this detailed study.

\section{OCCURRENCE}

The Pajsberg mine is a small deposit near the town of Persberg, Varmland County, Sweden, that produced about 3500 tons of manganese ore and 8500 tons of iron ore, closing in 1887. The manganese ore was granular, banded hausmannite in dolomite and the iron ore was quartz-hematite-magnetite. Pajsberg is one of the Långban-type ore deposits of the Bergslagen district of Sweden (Moore 1970). Långban-type deposits contain separated but associated zones of iron and manganese oxide ores, enclosed in Precambrian dolomitic marble. They are believed to be sedimentary-exhalative in origin, but have undergone high-grade metamorphism; several contain secondary, lower-temperature veins in which an enormous variety of unusual to unique mineral species have been found.

Two specimens of vesuvianite which were previously analyzed by Fitzgerald et al. (1992) were examined for this study. Both are from the Carl Bosch collection, now at the Smithsonian Institution; the catalog numbers are B20761 and B20770. Both consist of euhedral, cinnamon-red crystals of vesuvianite to 3 $\mathrm{mm}$ in size associated with pink olivine in the forsterite-tephroite series, in calcite-filled veins cutting granular, gneissic magnetite-quartz ore. The calcite is Mn-rich and fluoresces bright red in shortwave ultraviolet light. The specimens are each about $5 \mathrm{~cm}$ in maximum dimension, and the veins are about $0.5 \mathrm{~cm}$ wide. B20761, the chemically more anomalous of the two (Fitzgerald et al. 1992), was the focus of the study. An additional piece of B20761 obtained from the Smithsonian Institution was used for the spectroscopic studies. The study involved many false starts and blind paths and included efforts by a number of contributors over several years.

\section{Methods}

\section{Chemistry}

A crystal from B20761 was analyzed at Elemental Research Incorporated by laser ablation, inductioncoupled plasma, mass spectrometry (LA-ICP-MS), using pc detection mode and NBS612 glass standard for the trace elements. Major elements were analyzed by analog mode and are only semiquantitative. The results of this analysis are given in Table 1. The ESDs were not provided.

New electron microprobe analyses were obtained from newly mounted grains of each specimen at the Department of Mineral Sciences, Smithsonian Institution, using a JEOL 8900 Superprobe, operated at 15 $\mathrm{kV}$ and $20 \mathrm{nA}$. Primary standards used for analysis were: Kakanui hornblende (NMNH 143965) for Si, Al, $\mathrm{Fe}, \mathrm{Mg}, \mathrm{Ca}$, and $\mathrm{Ti}$; manganite (NMNH 157872) for $\mathrm{Mn}$; and arsenic metal for As. Secondary standards used were: diopside (NMNH 117733) for $\mathrm{Si}, \mathrm{Al}, \mathrm{Fe}$, and $\mathrm{Mg}$; Kakanui augite (NMNH 122142) for Si, Al, $\mathrm{Fe}, \mathrm{Mg}, \mathrm{Ca}, \mathrm{Ti}$, and $\mathrm{Mn}$; and fluorapatite $(\mathrm{NMNH}$ 104021) for As. Analytical uncertainty is about $1-3 \%$. Unfortunately, there was a miscommunication in the discussion of elements to be analyzed, and fluorine was not included in the new analyses. The analytical results are given in Table 2 .

\section{X-ray crystallography}

A single crystal of B20761 was selected from the sectioned samples, mounted with viscous oil, cooled to the $200 \mathrm{~K}$ data-collection temperature by a chilled nitrogen stream, and subjected to diffraction using a Bruker AXS SmartApex CCD diffractometer with graphite-monochromated $\operatorname{Mo} K \alpha$ radiation $(\lambda=$ $0.71073 \AA$ ). Crystal data and structure refinement information are given in Table 3 , and structure refinement data in Table 4 [Table 4 is available from the MAC Depository of Unpublished Data, document vesuvianite CM54-6_10.3749/canmin.1500051]. The data were treated with absorption corrections based on redundant multiscan data (Bruker 2007). Unit-cell parameters were determined by sampling three 
TABLE 1. LA-ICP-MS ANALYSIS OF VESUVIANITE FROM PAJSBERG, SWEDEN IN PPM BY WEIGHT

\begin{tabular}{|c|c|c|c|}
\hline Lithium & 0.3 & Antimony & 31.8 \\
\hline Beryllium & 2510 & Tellurium & 2.4 \\
\hline Boron & 1270 & lodine & 10.5 \\
\hline Sodium & 33.6 & Cesium & $<0.1$ \\
\hline Manganese & 33300 & & \\
\hline Aluminum & maj. cmp. & Barium & 0.3 \\
\hline Silicon & maj. cmp. & Lanthanum & 45.7 \\
\hline Phosphorous & 89.6 & Cerium & 74.2 \\
\hline Calcium & maj. cmp. & Praseodymium & 6.2 \\
\hline Scandium & 6.6 & Neodymium & 19.0 \\
\hline Titanium & 290 & & \\
\hline Vanadium & 22.5 & Europium & 2.1 \\
\hline Chromium & 72.5 & Samarium & 4.6 \\
\hline Manganese & maj cmp. & Gadolinium & 23.6 \\
\hline Iron & maj. cmp. & Terbium & 0.9 \\
\hline Cobalt & 17.9 & Dysprosium & 4.3 \\
\hline Nickel & 17.2 & & \\
\hline Copper & 261 & Holmium & 0.7 \\
\hline Zinc & 156 & Erbium & 1.9 \\
\hline Gallium & 7.8 & Thulium & 0.2 \\
\hline Gremanium & 190 & Ytterbium & 1.8 \\
\hline Arsenic & 2820 & Lutetium & 0.2 \\
\hline Selenium & $<0.1$ & & \\
\hline Rubidium & $<0.1$ & Hafnium & 0.8 \\
\hline \multirow[t]{2}{*}{ Strontium } & 88.2 & Tantalum & $<0.1$ \\
\hline & & Tungsten & $<0.1$ \\
\hline Yttrium & 19.7 & Rhenium & $<0.1$ \\
\hline Zirconium & 7.8 & Osmium & $<0.1$ \\
\hline Niobium & 0.4 & & \\
\hline Molybdenum & 0.3 & Iridium & $<0.1$ \\
\hline \multirow[t]{2}{*}{ Ruthenium } & $<0.1$ & Platinum & $<0.1$ \\
\hline & & Gold & $<0.1$ \\
\hline Rhodium & 0.4 & Mercury & 1.3 \\
\hline Palladium & 0.2 & Thalium & $<0.1$ \\
\hline Silver & $<0.1$ & & \\
\hline Cadmium & 0.2 & Lead & 1700 \\
\hline \multirow[t]{2}{*}{ Indium } & 0.8 & Bismuth & 23.3 \\
\hline & & Thorium & 0.2 \\
\hline Tin & 4.0 & Uranium & 12.1 \\
\hline
\end{tabular}

Note: Elements greater than $1 \%$ are only semi-quantitative; elements greater than $2 \%$ are listed as maj. $\mathrm{cmp}$. (major component).

different sections of the Ewald sphere. The systematic absences in the diffraction data, unit-cell parameters, and equivalent reflections are consistent with the reported space group, $P 4 / n c c$ (No. 130). The structure was solved using atomic coordinates from an isomorphic $\mathrm{Cu}$-rich vesuvianite from Franklin, New Jersey (Fitzgerald et al. 1986a), modified by the model for boron-bearing vesuvianite proposed by Groat et al. (1994b), and refined with full-matrix, least-squares procedures on $F^{2}$ with anisotropic displacement parameters. Corresponding substitutionally disordered, coincident atom pairs A11 and As; O11 and F11; Si2 and $\mathrm{As} 2$; and $\mathrm{Fe} 2$ and $\mathrm{Mg} 2$ were treated with equal atomic coordinates and equal atomic displacement parameters in order to refine the site occupancy ratios as independent free variables. Associated but not coincident disordered sites $\mathrm{Fe} 1$ and $\mathrm{Ca} 4$, and $\mathrm{B} 1$ and B2, which were freely allowed to refine in positions, were treated with equal atomic displacement parameters. Atomic scattering factors are contained in the SHELXTL program library (Sheldrick 2008).

All X sites were refined as $\mathrm{Ca}$, Y1 was refined as $\mathrm{Fe}, \mathrm{Y} 2$ as $\mathrm{A} 1$, and $\mathrm{Y} 3$ was split between $\mathrm{Mg}$ (proxying for $\mathrm{Mg}+\mathrm{Al}$ ) and $\mathrm{Fe}$ (proxying for $\mathrm{Fe}+\mathrm{Mn}$ ) but constrained to total 1 . X4 and Y1, adjacent sites along the four-fold axis that are each normally halfoccupied, were tied together with a total occupancy of 1 . Beryllium and B were tentatively assigned to T1 as B. After the first round of refinement it was apparent that $\mathrm{Si} 2$ contained excess electron density, so it was split into $\mathrm{Si}$ and As but constrained to total 1. The structure failed to converge to a satisfactory degree, so Y2 was split into $\mathrm{Al}$ and As, following Groat et al. (2013), T2 was allowed to refine as $\mathrm{B}$, and $\mathrm{O}(11)$ was split into $\mathrm{O}$ and $\mathrm{F}$. The structure refined to a final $\mathrm{R}$ of $1.88 \%$. Atomic positions and isotropic thermal parameters are given in Table 5, anisotropic temperature factors in Table 6, and selected bond lengths and angles in Table 7. Despite the low residuals attained, interpretation of the structure is not entirely straightforward because of the complexity of the substitutions involved.

Visible, near-infrared optical absorption spectroscopy

Optical absorption spectra were obtained from a crystal of B20761 with a Cary 17I spectrophotometer using a calcite Glan-Thompson polarizer. The sample was prepared as a doubly polished slab $108 \mu \mathrm{m}$ thick which contained the c-axis in the plane of the slab.

\section{Optics}

Indices of refraction were determined from a grain of B20761 mounted on a spindle stage, with an estimated accuracy of \pm 0.002 . Indices of refraction of immersion oils were determined using a Leitz Jelly refractometer.

\section{RESULTS}

\section{Chemistry}

The most notable features of the LA-ICP-MS analysis are that this vesuvianite contains $\sim 2 \% \mathrm{As}$, 1250 ppm by weight $\mathrm{B}$, or $0.40 \%$ by weight $\mathrm{B}_{2} \mathrm{O}_{3}$, and 
TABLE 2. ELECTRON MICROPROBE COMPOSITIONS OF PAJSBERG VESUVIANITES, AND ATOMIC PROPORTIONS CALCULATED ON THE BASIS OF 50 CATIONS

\begin{tabular}{lrrrrrr}
\hline & $\begin{array}{c}\text { B20761 } \\
\text { Left core }\end{array}$ & $\begin{array}{r}\text { B20761 } \\
\text { Left rim }\end{array}$ & $\begin{array}{c}\text { B20761 } \\
\text { Right core }\end{array}$ & $\begin{array}{c}\text { B20761 } \\
\text { Right rim }\end{array}$ & $\begin{array}{c}\text { B20770 } \\
\text { core }\end{array}$ & $\begin{array}{c}\text { B20770 } \\
\text { rim }\end{array}$ \\
\hline $\mathrm{SiO}_{2}$ & 34.89 & 34.38 & 34.59 & 34.42 & 34.82 & 34.98 \\
$\mathrm{As}_{2} \mathrm{O}_{5}$ & 1.20 & 1.63 & 1.47 & 1.59 & 0.99 & 1.15 \\
$\mathrm{Al}_{2} \mathrm{O}_{3}$ & 11.05 & 10.17 & 11.38 & 10.49 & 10.19 & 9.91 \\
$\mathrm{Fe}_{2} \mathrm{O}_{3}$ & 8.38 & 8.67 & 7.70 & 8.24 & 9.57 & 9.41 \\
$\mathrm{MgO}$ & 3.75 & 4.11 & 3.88 & 3.95 & 3.60 & 3.73 \\
$\mathrm{MnO}$ & 2.27 & 2.47 & 2.05 & 2.57 & 2.52 & 3.03 \\
$\mathrm{CaO}$ & 35.45 & 35.26 & 35.69 & 35.32 & 35.23 & 34.95 \\
$\mathrm{Total}$ & 97.02 & 96.78 & 96.79 & 96.66 & 96.93 & 97.17 \\
$\mathrm{Ca}$ & 18.96 & 18.95 & 19.02 & 18.97 & 18.9 & 18.73 \\
$\mathrm{Al}$ & 6.48 & 5.99 & 6.67 & 6.20 & 6.02 & 5.84 \\
$\mathrm{Fe}$ & 3.11 & 3.28 & 2.87 & 3.11 & 3.61 & 3.55 \\
$\mathrm{Mg}$ & 2.79 & 3.07 & 2.87 & 2.96 & 2.68 & 2.80 \\
$\mathrm{Mn}$ & 0.93 & 1.06 & 0.87 & 1.09 & 1.08 & 1.29 \\
$\mathrm{Si}$ & 17.43 & 17.22 & 17.31 & 17.26 & 17.45 & 17.50 \\
$\mathrm{As}$ & 0.30 & 0.42 & 0.39 & 0.42 & 0.27 & 0.30 \\
$\mathrm{Charge}$ & 145.34 & 145.10 & 145.35 & 145.24 & 145.37 & 145.31 \\
\hline
\end{tabular}

TABLE 3. CRYSTAL DATA AND STRUCTURE REFINEMENT PROCEDURES FOR PAJSBERG VESUVIANITE B20761

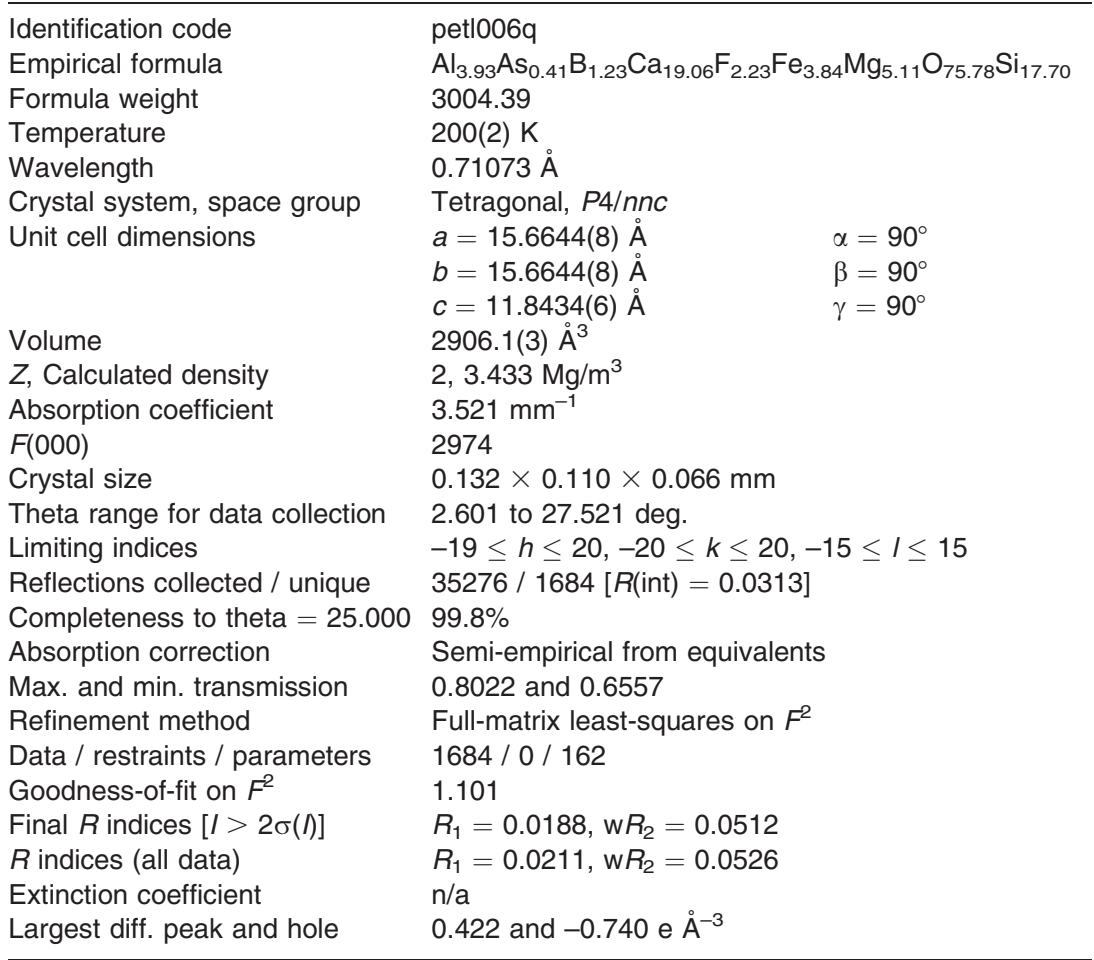


TABLE 5. ATOMIC POSITIONS AND THERMAL PARAMETERS FOR PAJSBERG VESUVIANITE B20761

\begin{tabular}{llccr}
\hline & $x$ & $y$ & $z$ & $U_{(\mathrm{eq})}$ \\
\hline Ca1 & 7500 & 2500 & 2500 & $10(1)$ \\
Ca2 & $8106(1)$ & $454(1)$ & $3789(1)$ & $8(1)$ \\
Ca3 & $8989(1)$ & $8200(1)$ & $8932(1)$ & $16(1)$ \\
Ca4 & 7500 & 7500 & $1448(1)$ & $13(1)$ \\
Fe1 & 7500 & 7500 & $435(1)$ & $13(1)$ \\
Al1 & 0 & 0 & 0 & $7(1)$ \\
As1 & 0 & 0 & 0 & $7(1)$ \\
Fe2 & $8888(1)$ & $1206(1)$ & $1266(1)$ & $5(1)$ \\
Mg2 & $8888(1)$ & $1206(1)$ & $1266(1)$ & $5(1)$ \\
Si1 & 7500 & 2500 & 0 & $7(1)$ \\
Si2 & $8201(1)$ & $399(1)$ & $8718(1)$ & $6(1)$ \\
As2 & $8201(1)$ & $399(1)$ & $8718(1)$ & $6(1)$ \\
Si3 & $9156(1)$ & $8495(1)$ & $3638(1)$ & $8(1)$ \\
B1 & $576(5)$ & $576(5)$ & 2500 & $17(3)$ \\
B2 & 2500 & 2500 & 2500 & $17(3)$ \\
O1 & $7784(1)$ & $1727(1)$ & $853(1)$ & $10(1)$ \\
O2 & $8820(1)$ & $1613(1)$ & $2820(1)$ & $10(1)$ \\
O3 & $9559(1)$ & $2240(1)$ & $741(1)$ & $10(1)$ \\
O4 & $9399(1)$ & $1051(1)$ & $4689(1)$ & $9(1)$ \\
O5 & $8282(1)$ & $116(1)$ & $1802(1)$ & $11(1)$ \\
O6 & $8786(1)$ & $7252(1)$ & $559(1)$ & $14(1)$ \\
O7 & $8298(1)$ & $9446(1)$ & $8178(1)$ & $18(1)$ \\
O8 & $9398(1)$ & $9081(1)$ & $689(1)$ & $9(1)$ \\
O9 & $8532(1)$ & $8532(1)$ & 2500 & $11(1)$ \\
O10 & 7500 & 7500 & $8666(2)$ & $16(1)$ \\
O11 & $9986(1)$ & $608(1)$ & $1364(1)$ & $13(1)$ \\
F11 & $9986(1)$ & $608(1)$ & $1364(1)$ & $13(1)$ \\
\hline
\end{tabular}

Note: Displacement parameters $\left(\AA^{2} \times 10^{3}\right) . U_{(\mathrm{eq})}$ is defined as one third of the trace of the orthogonalized $U_{i j}$ tensor.

$2450 \mathrm{ppm} \mathrm{Be}$, or 0.87 wt.\% $\mathrm{BeO}$. Arsenic has been reported in vesuvianite by Pan \& Fleet (1992), Groat \& Evans (2012), and Groat et al. (2013) in amounts up to $1.71 \% \quad \mathrm{As}_{2} \mathrm{O}_{5}$. Beryllium has been reported previously in amounts greater than $1 \% \mathrm{BeO}$ in vesuvianite from Franklin, New Jersey (Palache 1935, Palache \& Bauer 1930, Hurlbut 1955); Turnback Lake, Canada (Meen 1939); and Iron Mountains, New Mexico (Glass et al. 1944), but its location in the structure has not been determined.

Several differences between the EMP analyses in Fitzgerald et al. (1992) and these new ones are apparent: the totals are higher by about $2 \%, \mathrm{CaO}$ is higher by about $1 \%$, and both $\mathrm{SiO}_{2}$ and $\mathrm{Al}_{2} \mathrm{O}_{3}$ are somewhat higher; other elements are less strongly affected. The new chemical analyses that include As provide a basis for a new interpretation of the formula. Based on the optical spectroscopy (discussed below), $\mathrm{Fe}$ is considered exclusively $\mathrm{Fe}^{3+}$ and $\mathrm{Mn}$ exclusively
TABLE 6. ATOMIC POSITIONS AND THERMAL PARAMETERS FOR PAJSBERG VESUVIANITE B20761

\begin{tabular}{llccr}
\hline & $x$ & $y$ & $z$ & $U_{(\mathrm{eq})}$ \\
\hline X1 & 7500 & 2500 & 2500 & $10(1)$ \\
X2 & $8106(1)$ & $454(1)$ & $3789(1)$ & $8(1)$ \\
X3 & $8989(1)$ & $8200(1)$ & $8932(1)$ & $16(1)$ \\
X4 & 7500 & 7500 & $1448(1)$ & $13(1)$ \\
Y1 & 7500 & 7500 & $435(1)$ & $13(1)$ \\
Y2 & 0 & 0 & 0 & $7(1)$ \\
Y3 & $8888(1)$ & $1206(1)$ & $1266(1)$ & $5(1)$ \\
Z1 & 7500 & 2500 & 0 & $7(1)$ \\
Z2 & $8201(1)$ & $399(1)$ & $8718(1)$ & $6(1)$ \\
Z3 & $9156(1)$ & $8495(1)$ & $3638(1)$ & $8(1)$ \\
T1 & $576(5)$ & $576(5)$ & 2500 & $17(3)$ \\
T2 & 2500 & 2500 & 2500 & $17(3)$ \\
O1 & $7784(1)$ & $1727(1)$ & $853(1)$ & $10(1)$ \\
O2 & $8820(1)$ & $1613(1)$ & $2820(1)$ & $10(1)$ \\
O3 & $9559(1)$ & $2240(1)$ & $741(1)$ & $10(1)$ \\
O4 & $9399(1)$ & $1051(1)$ & $4689(1)$ & $9(1)$ \\
O5 & $8282(1)$ & $116(1)$ & $1802(1)$ & $11(1)$ \\
O6 & $8786(1)$ & $7252(1)$ & $559(1)$ & $14(1)$ \\
O7 & $8298(1)$ & $9446(1)$ & $8178(1)$ & $18(1)$ \\
O8 & $9398(1)$ & $9081(1)$ & $689(1)$ & $9(1)$ \\
O9 & $8532(1)$ & $8532(1)$ & 2500 & $11(1)$ \\
O10 & 7500 & 7500 & $8666(2)$ & $16(1)$ \\
O11 & $9986(1)$ & $608(1)$ & $1364(1)$ & $13(1)$ \\
F11 & $9986(1)$ & $608(1)$ & $1364(1)$ & $13(1)$ \\
\hline
\end{tabular}

Note: Displacement parameters $\left(\AA^{2} \times 10^{3}\right) . U_{(\mathrm{eq})}$ is defined as one third of the trace of the orthogonalized $U_{\mathrm{ij}}$ tensor.

$\mathrm{Mn}^{3+}$. The electron microprobe analyses can be converted to formulae by normalizing either to 19 $\mathrm{Ca}$ or to 50 cations, excluding $\mathrm{Be}+\mathrm{B}$. Normalizing to $19 \mathrm{Ca}$ gives an excess of about $0.1 \mathrm{Y}$-group cations (Groat et al. 1994a); however, normalizing to 50 cations gives a slight deficiency in $\mathrm{Ca}$ for the rims of both samples. The LA-ICP-MS analysis found 1700 ppm $\mathrm{Pb}$, which would substitute for $\mathrm{Ca}$. As $\mathrm{Mn}$ varies inversely with $\mathrm{Ca}$ between the cores and the rims, a small amount of $\mathrm{Mn}$ may also substitute for $\mathrm{Ca}$, at least in the rims, as previously suggested by Fitzgerald et al. (1992). We feel that normalizing to 50 cations gives the most coherent results; however, the differences between the two normalizing schemes are minor.

From the LA-ICP-MS analysis, B20761 also contains $2510 \mathrm{ppm} \mathrm{Be}, 1270 \mathrm{ppm} \mathrm{B}$, and $1700 \mathrm{ppm}$ $\mathrm{Pb}$ by weight. These are discussed below. The problems encountered by Fitzgerald et al. (1992) in normalizing the analyses to formulae are resolved by the new analyses; the new compositions of B20761 and B20770 are also not very different. 
TABLE 7. SELECTED BOND LENGTHS AND ANGLES FOR PAJSBERG VESUVIANITE B20761

\begin{tabular}{|c|c|c|c|}
\hline \multirow{2}{*}{\multicolumn{2}{|c|}{ FOR PAJSBERG VESUVIAN }} & \multirow{3}{*}{$\begin{array}{l}\mathrm{Z1}-\mathrm{O} 1 \\
\mathrm{Z1}-010\end{array}$} & \multirow{3}{*}{$\begin{array}{l}1.6389(13) \\
1.6389(13)\end{array}$} \\
\hline & & & \\
\hline $\mathrm{X} 1-\mathrm{O} 1$ & $2.3383(13)$ & & \\
\hline $\mathrm{X} 1-01$ & $2.3383(13)$ & Z1-O1 & $1.6389(13)$ \\
\hline $\mathrm{X} 1-\mathrm{O} 1$ & $2.3383(13)$ & 7?-07 & \\
\hline $\mathrm{X} 1-\mathrm{O} 1$ & $2.3383(13)$ & 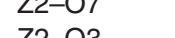 & $\begin{array}{l}1.6302(14) \\
1.6364(13)\end{array}$ \\
\hline $\mathrm{X} 1-\mathrm{O} 2$ & $2.5196(12)$ & $\angle 2-03$ & $\begin{array}{l}1.6364(13) \\
1.6476(13)\end{array}$ \\
\hline $\mathrm{X} 1-\mathrm{O} 2$ & $2.5196(13)$ & $22-02$ & $\begin{array}{l}1.6476(13) \\
16726(13)\end{array}$ \\
\hline $\mathrm{X} 1-\mathrm{O} 2$ & $2.5196(12)$ & $\angle 2-04$ & $1.6726(13)$ \\
\hline $\mathrm{X} 1-\mathrm{O} 2$ & $2.5196(13)$ & Z3-O6 & $1.6149(14)$ \\
\hline X2-08 & $23344(13)$ & Z3-O5 & $1.6265(14)$ \\
\hline X2-O5 & $\begin{array}{l}2.3344(13) \\
2.3440(13)\end{array}$ & Z3-O8 & $1.6270(13)$ \\
\hline $\mathrm{x} 2-\mathrm{O} 3$ & $2.3743(13)$ & Z3-O9 & $1.6654(8)$ \\
\hline$\times 2-02$ & $2.4208(13)$ & T1-O11 & $1.633(4)$ \\
\hline$\times 2-05$ & $2.4274(13)$ & T1-O11 & $1.633(4)$ \\
\hline$\times 2-01$ & $2.4704(13)$ & T1-07 & $1.939(7)$ \\
\hline X2-O4 & $2.4734(13)$ & T1-O7 & $1.939(7)$ \\
\hline X2-06 & $3.0352(15)$ & $\mathrm{T} 2-\mathrm{O} 10$ & $1.381(3)$ \\
\hline X3-07 & $2.4044(14)$ & T2-O10 & $1.381(3)$ \\
\hline X3-O3 & $2.4077(13)$ & O1-X1-O1 & $117.63(6)$ \\
\hline X3-06 & $2.4548(14)$ & $01-X 1-01$ & $66.97(6)$ \\
\hline X3-F11 & $2.4866(13)$ & $\mathrm{O} 1-\mathrm{X} 1-\mathrm{O} 1$ & $158.03(6)$ \\
\hline X3-011 & $2.4866(13)$ & O1-X1-O1 & $158.03(6)$ \\
\hline X3-08 & $2.5774(13)$ & $\mathrm{O} 1-\mathrm{X} 1-\mathrm{O} 1$ & $66.97(6)$ \\
\hline X3-010 & $2.5972(6)$ & $\mathrm{O} 1-\mathrm{X} 1-\mathrm{O} 1$ & $117.63(6)$ \\
\hline X3-07 & $2.6035(15)$ & $\mathrm{O} 1-\mathrm{X} 1-\mathrm{O} 2$ & $124.58(4)$ \\
\hline X3-07 & $2.6106(16)$ & $\mathrm{O} 1-\mathrm{X} 1-\mathrm{O} 2$ & $90.21(4)$ \\
\hline X3-06 & $2.8870(14)$ & O1-X1-02 & $71.56(4)$ \\
\hline X4-06 & $2.3061(15)$ & $\mathrm{O} 1-\mathrm{X} 1-\mathrm{O} 2$ & $75.23(4)$ \\
\hline X4-06 & $2.3061(15)$ & $\mathrm{O} 1-\mathrm{X} 1-\mathrm{O} 2$ & 71.56(4) \\
\hline X4-06 & $2.3061(15)$ & $\mathrm{O} 1-\mathrm{X} 1-\mathrm{O} 2$ & $75.23(4)$ \\
\hline X4-06 & $2.3061(15)$ & $\mathrm{O} 1-\mathrm{X} 1-\mathrm{O} 2$ & $124.58(4)$ \\
\hline X4-09 & $2.6045(18)$ & $\mathrm{O} 1-\mathrm{X} 1-\mathrm{O} 2$ & $90.21(4)$ \\
\hline X4-09 & $2.6045(18)$ & $\mathrm{O} 2-\mathrm{X} 1-\mathrm{O} 2$ & $162.67(6)$ \\
\hline X4-09 & $2.6045(18)$ & $\mathrm{O} 1-\mathrm{X} 1-\mathrm{O} 2$ & $75.23(4)$ \\
\hline X4-09 & $2.6045(18)$ & $\mathrm{O} 1-\mathrm{X} 1-\mathrm{O} 2$ & $71.56(4)$ \\
\hline & & $\mathrm{O} 1-\mathrm{X} 1-\mathrm{O} 2$ & $90.21(4)$ \\
\hline $\begin{array}{l}\mathrm{Y} 1-06 \\
\text { Y1-O6 }\end{array}$ & 2.0571(14) & $\mathrm{O} 1-\mathrm{X} 1-\mathrm{O} 2$ & $124.58(4)$ \\
\hline $\begin{array}{l}\mathrm{Y} 1-\mathrm{O} 6 \\
\mathrm{Y} 1-\mathrm{O}\end{array}$ & $2.0571(14)$ & $\mathrm{O} 2-\mathrm{X} 1-\mathrm{O} 2$ & 69.76(6) \\
\hline Y1-O6 & $2.0571(14)$ & $\mathrm{O} 2-\mathrm{X} 1-\mathrm{O} 2$ & $113.03(6)$ \\
\hline Y1-O6 & $2.0571(14)$ & $\mathrm{O} 1-\mathrm{X} 1-\mathrm{O} 2$ & $90.21(4)$ \\
\hline Y1-O10 & $2.094(3)$ & $\mathrm{O} 1-\mathrm{X} 1-\mathrm{O} 2$ & $124.58(4)$ \\
\hline Y2-O11 & $1.8757(13)$ & O1-X1-O2 & $75.23(4)$ \\
\hline Y2-O11 & $1.8757(13)$ & O1-X1-O2 & $71.56(4)$ \\
\hline Y2-08 & 1.9052(12) & $\mathrm{O} 2-\mathrm{X} 1-\mathrm{O} 2$ & $113.04(6)$ \\
\hline Y2-08 & $1.9052(12)$ & $\mathrm{O} 2-\mathrm{X} 1-\mathrm{O} 2$ & 69.76(6) \\
\hline Y2-O4 & $1.9317(12)$ & $\mathrm{O} 2-\mathrm{X} 1-\mathrm{O} 2$ & 162.67(6) \\
\hline Y2-O4 & $1.9317(12)$ & O8-X2-05 & $121.70(5)$ \\
\hline Y3-O2 & $1.9505(13)$ & $\mathrm{O} 8-\mathrm{X} 2-\mathrm{O} 3$ & 83.44(4) \\
\hline Y3-011 & $1.9615(13)$ & O5-X2-03 & 94.41(5) \\
\hline Y3-O1 & $1.9732(13)$ & O8-X2-02 & $110.79(4)$ \\
\hline Y3-O3 & $2.0292(14)$ & O5-X2-O2 & 117.12(5) \\
\hline Y3-O5 & $2.0549(14)$ & O3-X2-O2 & $124.97(5)$ \\
\hline Y3-O4 & $2.0970(13)$ & O8-X2-O5 & 91.61(4) \\
\hline Z1-O1 & $1.6389(13)$ & O5-X2-O5 & $76.48(5)$ \\
\hline
\end{tabular}

TABLE 7. CONTINUED 
TABLE 7. CONTINUED

\begin{tabular}{|c|c|c|c|}
\hline O3-X2-O5 & $165.39(5)$ & O10-X3-06 & $67.06(6)$ \\
\hline O2-X2-O5 & $69.63(4)$ & 07-X3-06 & $143.82(4)$ \\
\hline O8-X2-O1 & $153.63(4)$ & O7-X3-06 & $134.31(4)$ \\
\hline O5-X2-O1 & 73.14(4) & O6-X4-06 & 77.97(4) \\
\hline O3-X2-O1 & $73.19(4)$ & O6-X4-06 & $125.68(10)$ \\
\hline O2-X2-O1 & $74.72(4)$ & O6-X4-06 & $77.97(4)$ \\
\hline O5-X2-O1 & $113.97(4)$ & O6-X4-06 & $77.97(4)$ \\
\hline O8-X2-O4 & $67.55(4)$ & O6-X4-06 & $125.68(10)$ \\
\hline O5-X2-O4 & $166.85(5)$ & O6-X4-O6 & $77.97(4)$ \\
\hline O3-X2-O4 & 76.75(4) & O6-X4-09 & $149.96(3)$ \\
\hline O2-X2-O4 & $62.77(4)$ & $06-X 4-09$ & $130.99(3)$ \\
\hline O5-X2-O4 & $114.06(4)$ & O6-X4-09 & $64.60(4)$ \\
\hline O1-X2-O4 & $94.77(4)$ & O6-X4-09 & $77.34(4)$ \\
\hline O8-X2-06 & $67.12(4)$ & $06-X 4-09$ & $64.60(4)$ \\
\hline O5-X2-O6 & $58.18(4)$ & O6-X4-09 & 77.34(4) \\
\hline O3-X2-O6 & 69.16(4) & O5-X4-09 & $149.96(3)$ \\
\hline O2-X2-O6 & $165.83(4)$ & O6-X4-09 & $130.99(3)$ \\
\hline O5-X2-O6 & $96.25(4)$ & 09-X4-09 & $122.84(7)$ \\
\hline O1-X2-O6 & $113.72(4)$ & O6-X4-09 & 77.34(4) \\
\hline O4-X2-O6 & $125.25(4)$ & O6-X4-09 & $149.96(3)$ \\
\hline O7-X3-011 & $68.24(5)$ & O6-X4-O9 & $130.99(3)$ \\
\hline O3-X3-011 & $68.18(4)$ & O6-X4-09 & $64.60(4)$ \\
\hline O6-X3-011 & $130.46(5)$ & O9-Х4-09 & 76.77(3) \\
\hline O7-X3-08 & $88.70(4)$ & O9-X4-09 & 76.77(3) \\
\hline O3-X3-08 & $77.81(4)$ & O6-X4-09 & 130.99(3) \\
\hline O6-X3-08 & $73.86(4)$ & O6-X4-09 & $64.60(4)$ \\
\hline F11-X3-08 & $63.38(4)$ & O6-X4-09 & 77.34(4) \\
\hline O11-X3-08 & $63.38(4)$ & O6-X4-09 & 149.96(3) \\
\hline O7-X3-O10 & 83.87(4) & O9-X4-09 & 76.77(3) \\
\hline O3-X3-O10 & $138.30(4)$ & O9-X4-09 & $122.84(7)$ \\
\hline O6-X3-010 & $73.90(6)$ & O6-Y1-O6 & $171.79(10)$ \\
\hline F11-X3-O10 & $151.64(5)$ & O6-Y1-O6 & $89.707(8)$ \\
\hline O11-X3-010 & $151.64(5)$ & O6-Y1-O6 & 89.706(8) \\
\hline O8-X3-010 & $123.13(6)$ & O6-Y1-O6 & $89.706(8)$ \\
\hline O7-X3-07 & $73.75(6)$ & O6-Y1-O6 & $89.708(8)$ \\
\hline O3-X3-O7 & 84.94(4) & O6-Y1-O6 & 171.79(10) \\
\hline O6-X3-O7 & $145.55(5)$ & O6-Y1-O10 & $94.10(5)$ \\
\hline F11-X3-O7 & $69.11(5)$ & O6-Y1-O10 & $94.10(5)$ \\
\hline O11-X3-07 & $69.11(5)$ & O6-Y1-O10 & $94.10(5)$ \\
\hline O8-X3-07 & $132.49(5)$ & O6-Y1-O10 & $94.10(5)$ \\
\hline O10-X3-07 & $98.95(7)$ & O11-Y2-011 & $180.00(11)$ \\
\hline $\begin{array}{l}\text { O7-X3-O7 } \\
\text { O3-X3-O7 }\end{array}$ & $\begin{array}{r}136.58(7) \\
62.51(4)\end{array}$ & $\begin{array}{l}011-Y 2-011 \\
\text { O11-Y2-O8 }\end{array}$ & $90.52(5)$ \\
\hline O6-X3-07 & $76.10(4)$ & O11-Y2-O8 & $89.48(5)$ \\
\hline $\mathrm{F} 11-\mathrm{X} 3-\mathrm{O} 7$ & $116.71(5)$ & O11-Y2-O8 & $89.48(5)$ \\
\hline O11-X3-07 & $116.71(5)$ & O11-Y2-08 & $90.52(5)$ \\
\hline O8-X3-07 & $133.55(4)$ & O8-Y2-08 & $180.00(10)$ \\
\hline O10-X3-07 & 79.94(4) & O11-Y2-O4 & $95.37(5)$ \\
\hline O70-X3-07 & $69.46(5)$ & O11-Y2-O4 & $84.63(5)$ \\
\hline O7-X3-06 & $71.72(5)$ & O8-Y2-O4 & $88.42(5)$ \\
\hline O3-X3-06 & $\begin{array}{r}11.2(5) \\
128.26(4)\end{array}$ & O8-Y2-O4 & $91.58(5)$ \\
\hline O6-X3-06 & $\begin{array}{r}128.26(4) \\
65.22(5)\end{array}$ & O11-Y2-O4 & $84.63(5)$ \\
\hline $\mathrm{F} 11-\mathrm{X} 3-\mathrm{O} 6$ & $\begin{array}{r}65.22(5) \\
106.87(4)\end{array}$ & O11-Y2-O4 & $95.37(5)$ \\
\hline O11-X3-06 & $106.87(4)$ & O8-Y2-O4 & $91.58(5)$ \\
\hline O8-X3-06 & $\begin{array}{r}57.17(4) \\
\text { (1) }\end{array}$ & O8-Y2-O4 & $88.42(5)$ \\
\hline
\end{tabular}

TABLE 7. CONTINUED 
TABLE 7. CONTINUED

\begin{tabular}{|c|c|}
\hline O4-Y2-O4 & $180.00(10)$ \\
\hline O2-Y3-O11 & $98.53(5)$ \\
\hline O2-Y3-O1 & $92.91(5)$ \\
\hline O11-Y3-O1 & $168.55(6)$ \\
\hline O2-Y3-O3 & $93.30(5)$ \\
\hline O11-Y3-O3 & $86.86(5)$ \\
\hline O1-Y3-O3 & $92.73(5)$ \\
\hline O2-Y3-O5 & $87.39(5)$ \\
\hline O11-Y3-O5 & $89.43(5)$ \\
\hline O1-Y3-O5 & $90.87(5)$ \\
\hline O3-Y3-O5 & $176.29(5)$ \\
\hline O2-Y3-O4 & $172.14(5)$ \\
\hline O11-Y3-O4 & $78.27(5)$ \\
\hline O1-Y3-O4 & $90.35(5)$ \\
\hline O3-Y3-O4 & $93.69(5)$ \\
\hline O5-Y3-O4 & $85.42(5)$ \\
\hline O1-Z1-O1 & $112.35(5)$ \\
\hline O1-Z1vO10 & 103.85(9) \\
\hline O1-Z1-O10 & $112.35(5)$ \\
\hline O1-Z1-O1 & $112.35(5)$ \\
\hline O1-Z1-O1 & $103.85(9)$ \\
\hline O10-Z1-O1 & $112.35(5)$ \\
\hline O7-Z2-O3 & $106.04(8)$ \\
\hline O7-Z2-O2 & $114.24(7)$ \\
\hline O3-Z2-O2 & $112.71(7)$ \\
\hline O7-Z2-O4 & $112.18(7)$ \\
\hline O3-Z2-O4 & $111.52(7)$ \\
\hline O2-Z2-O4 & $100.31(7)$ \\
\hline O6-Z3-O5 & $111.79(7)$ \\
\hline O6-Z3-O8 & $108.36(7)$ \\
\hline O5-Z3-08 & $113.75(7)$ \\
\hline O6-Z3-09 & $106.95(8)$ \\
\hline O5-Z3-O9 & $106.85(6)$ \\
\hline O8-Z3-O9 & $108.88(6)$ \\
\hline O11-T1-O11 & $135.5(7)$ \\
\hline O11-T1-O7 & $107.63(16)$ \\
\hline O11-T1-O7 & $100.06(15)$ \\
\hline O11-T1-O7 & $100.06(15)$ \\
\hline O11-T1-O7 & $107.63(16)$ \\
\hline O7-T1-O7 & $101.8(5)$ \\
\hline O10-T2-O10 & 180.0 \\
\hline O10-T2-X3 & 123.332(9) \\
\hline O10-T2-X3 & 56.668(9) \\
\hline O10-T2-X3 & 56.668(9) \\
\hline O10-T2-X3 & 123.332(9) \\
\hline
\end{tabular}

Note: Lengths in Angstroms, angles in degrees. ESDs in parentheses.

Visible, near-infrared optical absorption spectroscopy

Interpretation of the optical absorption spectrum (Fig. 1) is not straightforward. In the ultraviolet range from 350 to $400 \mathrm{~nm}$, the spectrum is dominated by an

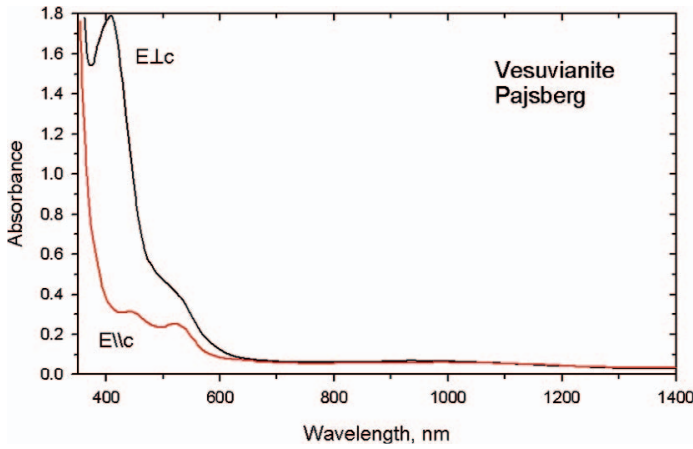

FIG. 1. Optical absorption spectrum of the Pajsberg vesuvianite obtained with light polarized parallel and perpendicular to the c-axis of a $0.180 \mathrm{~mm}$-thick slab.

intense absorption which tails into the visible portion of the spectrum. In the visible region, the most intense band, centered at about $415 \mathrm{~nm}$, is polarized in the $\mathrm{E} \perp \mathrm{c}$ direction. Two less-intense bands occur at 451 $\mathrm{nm}$ (present in the $\mathrm{E} / \mathrm{c}$ direction, but possibly obstructed in the $\mathrm{E} \perp \mathrm{c}$ direction) and at $531 \mathrm{~nm}$ (present in both polarizations). There is also a hint of a weak feature near $1015 \mathrm{~nm}$.

First consider the role of iron. If the iron is mostly $\mathrm{Fe}^{2+}$, Manning (Manning \& Tricker 1975, Manning 1968 ) indicates that the absorption bands would be near 830 and $1110 \mathrm{~nm}$. He does not provide an epsilon value for the $\mathrm{Fe}^{2+}$, but typical values for $\mathrm{Fe}^{2+}$ in sites of low distortion are around 10. This leads to the expectation of a band of at least 0.37 absorbance units in this wavelength region. No such bands are present. And, if the iron were at sites with distorted octahedral coordination, the intensity would be even higher. Thus we can conclude that $\mathrm{Fe}^{2+}$ is absent, or at best only a minor component of the iron in the Pajsberg vesuvianite, possibly causing the weak feature near $1015 \mathrm{~nm}$.

The optical spectra indicate that the iron is mostly $\mathrm{Fe}^{3+}$. Manning (Manning 1968, Manning \& Tricker 1975) established that the absorption of $\mathrm{Fe}^{3+}$ is at about $463 \mathrm{~nm}$ with greatest intensity in the Ellc direction with an intensity given by the epsilon value of 1.5 if the $\mathrm{Fe}^{3+}$ is at the octahedral sites. Given these assumptions, one can calculate from Beer's Law that a $463 \mathrm{~nm}$ band in the Pajsberg sample would have an absorbance of only about 0.056 . Such a band would be barely seen in the spectrum of Figure 1, and, in fact, is not seen, suggesting that some of the iron is not at the octahedral sites.

The possibility arises that some of the features in the Pajsberg vesuvianite spectrum are from $\mathrm{Mn}^{2+}$. At sites with approximately octahedral coordination, $\mathrm{Mn}^{2+}$ has a spectrum with bands near 412,450 , and 
$550 \mathrm{~nm}$, so this possibility must be considered. Because $\mathrm{Mn}^{2+}$ bands are spin-forbidden, they are very weak, and, based on an intensity argument assuming a molar absorptivity (epsilon value) of 1.0 for the 411 $\mathrm{nm}$ band, the Pajsberg vesuvianite would have to have a $\mathrm{Mn}^{2+}$ concentration of at least 74 moles/liter (more than $100 \% \mathrm{MnO}$ by weight) to provide the absorption intensity observed in its spectrum. Such a high concentration is physically impossible. Even an epsilon of 1.0 is high for many $\mathrm{Mn}^{2+}$ phases. For example, the epsilon of the equivalent band (at 396.5 $\mathrm{nm}$ ) in $\mathrm{NaMnF}_{3}$ at $80 \mathrm{~K}$ is about 0.22 (Srivastava \& Mehra 1972), which would demand an even higher concentration of $\mathrm{Mn}$ to give the observed spectrum.

The role of $\mathrm{Mn}^{3+}$ is suggested by the fact that many minerals that have modest concentrations of $\mathrm{Mn}^{3+}$ at a six-coordinated site are red in color, as is the Palsberg vesuvianite. Such phases with $\mathrm{Mn}^{3+}$ are subject to Jahn-Teller distortion and commonly have an intense absorption band in their optical spectra in the 450 to $550 \mathrm{~nm}$ region and a weaker, lower-energy component whose separation from the dominant band depends upon the magnitude of the distortion of the site coordination from octahedral symmetry.

The feature near $531 \mathrm{~nm}$ in the Pajsberg vesuvianite spectrum is consistent with the dominant $\mathrm{Mn}^{3+}$ feature in the spectrum of lilac vesuvianite from Naslawice, Poland (Platonov et al. 1995) and in the spectrum of lilac $\mathrm{Mn}^{3+}$-bearing vesuvianite from Asbestos, Quebec, Canada (Rossman 2015). However, unlike these spectra, the $531 \mathrm{~nm}$ band in the Pajsberg spectrum is not the most intense feature; rather, the $415 \mathrm{~nm}$ band is the dominant feature, which is at an unusual position for $\mathrm{Mn}^{3+}$.

There are two literature spectra of vesuvianite with similar intense features at similarly short wavelengths assigned to $\mathrm{Mn}^{3+}$ (Platonov et al. 1995). The 415 feature of the Pajsberg spectrum resembles the $424 \mathrm{~nm}$ dominant features in the spectra of the pink vesuvianite from Naslawice, Poland, and a similar spectrum from yellow vesuvianite from Jordanow, Poland. Each of these spectra adds credence to the possibility that the Pajsberg vesuvianite is dominated by $\mathrm{Mn}^{3+}$.

Some uncertainties in the assignment remain. The full-width at half-height of the $415 \mathrm{~nm}$ band is about $3350 \mathrm{~cm}^{-1}$, which is about halfway between the widths commonly seen for crystal-field transitions of individual cations and the widths of intervalence chargetransfer bands (Mattson \& Rossman 1987). One possible explanation is that $\mathrm{Mn}$ occupies multiple crystal sites. The chemical analyses above show that the dominant transition metal ion in the Pajsberg vesuvianite is $\mathrm{Fe}$, and charge-balance considerations and optical spectra strongly suggest that it is dominantly present as $\mathrm{Fe}^{3+}$. This raises the possibility that $\mathrm{Mn}^{2+}-\mathrm{Fe}^{3+}$ interactions of the type discussed by Smith et al. (1983) may contribute to the spectrum. Smith et al. (1983) considered the interaction between pairs of $\mathrm{Mn}^{2+}(\mathrm{VI})$ and $\mathrm{Fe}^{3+}(\mathrm{IV})$ ions, each with a $d^{5}$ electron configuration, and thus with only spinforbidden bands, which produce high-intensity absorption when the two ions interact with incident light in concert. Although the alternate case of interactions between octahedrally coordinated $\mathrm{Mn}^{2+}$ and $\mathrm{Fe}^{3+}$ pairs has not been experimentally demonstrated, interactions between pairs of octahedrally coordinated $\mathrm{Fe}^{3+}$ ions in minerals has been well documented (Rossman 1975). Interactions between cations at the T2 site with the Y3 site could contribute to the spectrum in the Ellc direction, but the information at hand does not establish that possibility.

\section{Optics}

The sample is optically negative and faintly biaxial, with $2 \mathrm{~V}<5^{\circ}$. Indices are $\varepsilon=1.733(0.002), \omega=$ $1.738(0.002)$; pleochroism is $\mathrm{E}$ pale orange brown, $\mathrm{O}$ orange brown. This is in contrast to the much stronger pleochroism from colorless-yellowish to dark red-lilac observed in manganvesuvianite from the Kalahari manganese fields, South Africa (Armbruster et al. 2002), which contains 15.96 wt. $\% \mathrm{Mn}_{2} \mathrm{O}_{3}$ at $\mathrm{Y} 1$ and Y3. Wiluite, the vesuvianite-group mineral with the $\mathrm{T}$ site at least one-half occupied by B, is optically positive.

\section{DisCUSSION}

\section{Site occupancy}

Some differences between this refinement and those of Groat et al. (1994b) should be mentioned: there is no indication of an $\mathrm{O} 12$ position in this structure, despite the indicated small occupancy of $\mathrm{T} 2$. Also, despite the fairly large thermal parameters of $\mathrm{O} 7$ and $\mathrm{O} 10$, a satisfactory refinement was attained without splitting these sites into $\mathrm{a}$ and $\mathrm{b}$ positions.

$\mathrm{X} 1, \mathrm{X} 2$, and $\mathrm{X} 3$ refine as only $\mathrm{Ca}$. $\mathrm{X} 4$, on the fourfold axis, is close to Y1. Both are sites of occupancy 2, but because of their proximity, adjacent $\mathrm{X} 4$ and $\mathrm{Y} 1$ sites cannot both be occupied. The two sites are typically both one-half occupied. In this structure $\mathrm{X} 4$ refined as $0.53 \mathrm{Ca}$ (1.06 atoms) and $\mathrm{Y} 1$ as $0.47 \mathrm{Fe}(0.94$ atoms). These values may reflect actual site occupancy, or some heavier atom may substitute for $\mathrm{Ca}$ at $\mathrm{X} 4$, raising its apparent occupancy. The substitution of $\mathrm{Pb}$ or $\mathrm{Mn}$ for $\mathrm{Ca}$ at $\mathrm{X} 4$ would raise the electron density and apparent occupancy of the site. In particular, the amount of lead from the LA-ICP-MS analysis gives 0.02 atoms of $\mathrm{Pb}$ in the formula, equivalent in electron density to $0.10 \mathrm{Ca}$, enough to increase the apparent 
proportion of $\mathrm{Ca}$ at $\mathrm{X} 4$ by more than the required amount. However, X3 has longer bond lengths than X4 and $\mathrm{Pb}^{2+}(r=1.20 \AA)$ would be expected to favor the larger site, although X3 refined as solely Ca. Overall, bond-length considerations, the chemical analysis, and the structural refinement are compatible with X4 containing enough lead ( 0.014 atom) to account for the higher apparent occupancy, with the balance being at $\mathrm{X} 3$, and that is the interpretation adopted here.

The $\mathrm{Y}$ sites are more complicated than the $\mathrm{X}$ sites. When the Y1 site along the four-fold axis of the structure contains $\mathrm{Cu}^{2+}$ (Fitzgerald et al. 1986a) or $\mathrm{Mn}^{3+}$ (Armbruster et al. 2002) it shows Jahn-Teller distortion, with a relative lengthening of the $\mathrm{Y} 1-\mathrm{O}(10)$ distance. This site is five-coordinated, essentially an octahedral site missing one apex ligand. In manganvesuvianite the difference between the $\mathrm{Y} 1-\mathrm{O} 10$ distance and the Y1-O6 distance $\mathrm{O}(10)-\mathrm{O}(6)$ is +0.150 for the more distorted of the two Y1 sites, and for $\mathrm{Cu}$-rich vesuvianite it is +0.235 . The Pajsberg sample has a $\mathrm{O}(10)-\mathrm{O}(6)$ bond-length difference of (2.094-2.057 $=+0.037)$, and does not show JahnTeller distortion; therefore, we conclude that Y1 does not contain $\mathrm{Mn}^{3+}$. The site refined as $\mathrm{Fe}$, and the average bond length, $2.0575 \AA$, is more compatible with $\mathrm{Fe}^{3+}$ than $\mathrm{Fe}^{2+}$ or $\mathrm{Mn}^{2+}$. When $\mathrm{Y} 1$ is occupied by a trivalent cation, the adjoining $\mathrm{O} 10$ site is occupied by oxygen, not hydroxyl (Fitzgerald et al. 1986b); thus $\mathrm{O} 10$ is $\mathrm{O}(\mathrm{OH})$ rather than $2 \mathrm{O}$. The $\mathrm{Y} 2$ and $\mathrm{Y} 3$ sites form an edge-sharing trimer $\mathrm{Y} 3-\mathrm{Y} 2-\mathrm{Y} 3$, cross-linked to adjacent trimers by $\mathrm{Si} 2$, through $\mathrm{O} 2$ and $\mathrm{O} 4$. The tetrahedrally coordinated $\mathrm{T} 1$ site lies between adjacent bands. The Y2 site is occupied exclusively by $\mathrm{Al}$ in almost all known vesuvianites, but Groat et al. (2013) found a small amount (4.6\%) occupied by As. In the Pajsberg vesuvianite, refinement of $\mathrm{Y} 2$ as $\mathrm{Al}+\mathrm{As}$ shows $2 \%$ occupancy by As $(0.08 \mathrm{As})$ at $\mathrm{Y} 2$.

$\mathrm{Y} 3$, the general site in vesuvianite, contains a wide variety of di- and tri-valent cations; in Pajsberg vesuvianite $\mathrm{Mg}^{2+}, \mathrm{Al}^{3+}, \mathrm{Mn}$, and $\mathrm{Fe}$ are all assigned to $\mathrm{Y} 3$. The site was refined as $\mathrm{Mg}+\mathrm{Fe}$, with the total constrained to 1 , which gave $\mathrm{Mg} 0.64$ and $\mathrm{Fe} 0.36$ or $\mathrm{Mg}_{5.12} \mathrm{Fe}_{2.88}$. In interpreting the actual contents of $\mathrm{Y} 3$, all $\mathrm{Mg}$ was assigned to the site, with enough $\mathrm{Al}$ to make up the "Mg" portion, and all Mn was assigned to the site, with enough $\mathrm{Fe}$ to make up the "Fe" portion. The derived chemistry of the site is $\mathrm{Mg} 2.83, \mathrm{Al} 2.29$, $\mathrm{Mn} 0.90, \mathrm{Fe} 1.98$. If $\mathrm{Mn}$ is regarded as trivalent, the indicated charge at $\mathrm{Y} 3$ is lower (21.17) at the site than in ideal vesuvianite (22), and if $\mathrm{Mn}$ is regarded as divalent, the charge is significantly lower (20.27).

The average bond length around the $\mathrm{Y} 3$ site is $2.011 \AA$, and the bond range is $0.147 \AA$; for comparison, the Al-rich, Fe-free vesuvianite studied by Fitzgerald et al. (1986b) has average bond length
$1.950 \AA$ and range $0.122 \AA$ for the same site, suggesting relatively little polyhedral distortion. The bond angles around Y3 (Table 6) also show relatively little distortion.

The Z1 site, of multiplicity 2, is occupied exclusively by $\mathrm{Si}$; the $\mathrm{Z} 2$ site (multiplicity 8 ) refined to $\mathrm{Si}_{0.96} \mathrm{As}_{0.04}$; and the $\mathrm{Z3}$ site (also multiplicity 8, forming $\mathrm{Si}_{2} \mathrm{O}_{7}$ groups) also refined to exclusively $\mathrm{Si}$. The refined amounts of As at Y2 and Z2 account for all the arsenic determined by electron microprobe analysis; thus, no As was assigned to any other position. The formula on the basis of 50 cations has a $\mathrm{Si}+\mathrm{As}$ total of $17.37+0.32=17.71$, suggesting substitution of $0.29 \mathrm{Al}$ for $\mathrm{Si}$. The three $\mathrm{Si}$ sites have similar bond lengths $(1.64,1.65$, and $1.63 \AA$, respectively); however, the Si2 site is bonded to Y2, Y3, and T1, which provide a number of possible balancing substitutions, discussed below, so $0.29 \mathrm{Al}$ is assigned to $\mathrm{Z} 2$.

The formula derived from the LA-ICP-MS analysis gave $0.82 \mathrm{Be}$ and $0.35 \mathrm{~B}$, or $1.0306 \mathrm{~B}$ equivalent structurally. The structural analysis gave $0.31 \mathrm{~B}$ occupancy at $\mathrm{T}_{4}$ (1.24 $\mathrm{B}$ atoms equivalent). If all $\mathrm{Be}$ and $\mathrm{B}$ are assigned to $\mathrm{T} 1$, there is an excess of electron density at the site equivalent to $0.21 \mathrm{~B}$. If a small amount of some heavier cation is present at the site as per Groat et al. (1994a), it would account for the discrepancy; $0.037 \mathrm{Fe}$ could make up the difference and involves the least incompatibility with the chemical analysis. Because of its smaller size and preference for distorted environments, we assumed that it is present as $\mathrm{Fe}^{3+}$. Having $\mathrm{Fe}^{3+}$ at the site rather than $\mathrm{Fe}^{2+}, \mathrm{Mg}$, or $\mathrm{Al}$ would also be compatible with the optical absorption spectrum if at least some Mn at Y3 were divalent, although that is not the interpretation adopted here. However, the attempt to refine T1 as partly Fe resulted in a significantly higher $R$ factor.

The T2 site refined as $0.04 \mathrm{~B}$ with two T2-O10 bond lengths of $1.381 \AA$; similar very short bond lengths were determined by Groat et al. (1994b). As there is no additional oxygen site (O12 of Groat et al. 1994b) to help balance T2, it seems more likely that the site represents a disordered $\mathrm{H}$ position forming an $\mathrm{OH}$ group with $\mathrm{O} 10$ (Groat et al. 1994b). Table 8 gives the cation site contents derived from this interpretation, and Table 9 gives the average core value from EMP analysis and the composition calculated from the structural analysis.

\section{Charge balance}

Groat et al. (1994b) showed that $\mathrm{B}$ at $\mathrm{T}_{4}$ is balanced mostly by the exchange $\mathrm{BMgH}_{2} \mathrm{Al}_{1}$, that is, by removing $2 \mathrm{H}$ from $\mathrm{O}_{1} 1_{8}$, which is typically $\mathrm{OH}$, and substituting $\mathrm{Mg}\left(\right.$ or $\mathrm{Fe}^{2+}, \mathrm{Mn}^{2+}$ ) for $\mathrm{Al}\left(\right.$ or $\mathrm{Fe}^{3+}$ ) at 
TABLE 8. SITE CONTENTS FOR PAJSBERG VESUVIANITE B20761 FROM STRUCTURAL ANALYSIS

\begin{tabular}{ll}
\hline Site & \multicolumn{1}{c}{ Contents } \\
\hline $\mathrm{X} 1_{2}$ & $\mathrm{Ca}_{8}$ \\
$\mathrm{X} 2_{8}$ & $\mathrm{Ca}_{8}$ \\
$\mathrm{X} 3_{8}$ & $\mathrm{Ca}_{7.96} \mathrm{~Pb}_{0.01}$ \\
$\mathrm{X} 4_{1}$ & $\mathrm{Ca}_{0.99} \mathrm{~Pb}_{0.01}$ \\
$\mathrm{Y} 1_{1}$ & $\mathrm{Fe}^{3+}{ }_{1}$ \\
$\mathrm{Y}_{4}$ & $\mathrm{Al}_{3.92} \mathrm{As}_{0.08}$ \\
$\mathrm{Y}_{8}$ & $\mathrm{Mg}_{2.83} \mathrm{Al}_{2.29} \mathrm{Mn}^{3+}{ }_{0.90} \mathrm{Fe}^{3+}{ }_{1.98}$ \\
$\mathrm{Z1}_{2}$ & $\mathrm{Si}_{2}$ \\
$\mathrm{Z}_{8}$ & $\mathrm{Si}_{7.37} \mathrm{As}_{0.32} \mathrm{Al}_{0.31}$ \\
$\mathrm{Z}_{8}$ & $\mathrm{Si}_{8}$ \\
$\mathrm{~T}_{4}$ & $\mathrm{Be}_{0.82} \mathrm{~B}_{0.35} \mathrm{Fe}^{3+}{ }_{0.037}$ \\
\hline
\end{tabular}

$\mathrm{Y} 3$. If $\mathrm{Be}$ is at $\mathrm{T} 1$, both $\mathrm{H}$ atoms bonded to $\mathrm{O} 11$ must be absent, and their removal balances Be without any cation exchange at $\mathrm{Y} 3$. If As is at $\mathrm{Y} 2$, it requires an additional -2 charge in the adjoining anions, or a decrease of +2 charge at the adjoining $\mathrm{Y} 3$ or $\mathrm{Si} 2$ sites. The Y2 site is bonded to 2O11, and loss of both the $\mathrm{H}$ atoms bonded to them $\left(\mathrm{AsAl}_{-1} \mathrm{H}_{-2}\right)$ balances the As without any other substitution. The Y2 position is also bonded to $2 \mathrm{Y} 3$ through $\mathrm{O} 4$ and $\mathrm{O} 11$, and substitution of $\mathrm{Mg}$ for two $\mathrm{Al}$ at $\mathrm{Y} 3$ would balance As at $\mathrm{Y} 2$ $\left(\mathrm{AsMgAl}_{1} \mathrm{Al}_{2}\right)$. Finally, Y2 is bonded to two $\mathrm{Si} 2$ through $\mathrm{O} 4$, and the substitution of $\mathrm{Al}$ for $\mathrm{Si}$ at two adjoining $\mathrm{Si} 2$ would also balance As substituting for $\mathrm{Al}$ at $\mathrm{Y} 2\left(\mathrm{AsAl}_{2} \mathrm{Al}_{1} \mathrm{Si}_{2}\right)$. Because $\mathrm{Y} 3$ shows an unusually low charge total and there appears to be considerable $\mathrm{Al}$ for Si substitution, most likely at Si2, either of the second two substitutions are plausible. If the first substitution is predominant, the $\mathrm{T} 1$ site adjacent to a Y2 site containing As could not contain $\mathrm{Be}$ or $\mathrm{B}$, as these ions are also balanced by loss of $\mathrm{H}$ from $\mathrm{O} 11$.

The majority of As in the structure is at the Z2 site, substituting for $\mathrm{Si}$. The $\mathrm{Si}$ atom is bonded to $\mathrm{O} 2, \mathrm{O} 3$, $\mathrm{O} 4$, and $\mathrm{O} 7$ with bonds through $\mathrm{O} 2$ and $\mathrm{O} 4$ to $\mathrm{Y} 3$. Substitution of $\mathrm{Mg}$ for $\mathrm{Al}$ at $\mathrm{Y} 3$ would compensate for the As at $\mathrm{Z} 2\left(\mathrm{AsMgSi}_{1} \mathrm{Al}_{1}\right)$.

Incorporation of $\mathrm{Be}$ at $\mathrm{T} 1$ involves loss of $2 \mathrm{H}$ from $\mathrm{O} 11$, as does incorporation of $\mathrm{B}$ or $\mathrm{Fe}^{3+}$ at $\mathrm{T} 1$. Together, these substitutions require loss of $1.64+$ $0.70+0.04=2.38 \mathrm{H}$ per formula from $\mathrm{O} 11$, resulting in a formula content of $\mathrm{O}_{2.38} \mathrm{OH}_{5.62}$ for O11. Finally, the substitution of $2.23 \mathrm{~F}$ for $\mathrm{OH}$ at $\mathrm{O} 11$, indicated by the structural analysis, would yield $\mathrm{O}_{2.46} \mathrm{OH}_{3.31} \mathrm{~F}_{2.23}$ and a negative charge of 10.46. [Fitzgerald et al. (1992) found only $0.35 \mathrm{~F}$ in their analysis of Pajsberg vesuvianite, substantially less than indicated by the current structural analysis.] Both $\mathrm{B}$ or $\mathrm{Fe}^{3+}$ at $\mathrm{T} 1$ and
TABLE 9. AVERAGE CORE COMPOSITION OF PAJSBERG VESUVIANITE B50761 FROM TABLE 2, AND COMPOSITION CALCULATED FROM STRUCTURAL ANALYSIS, WITH ATOMIC PROPORTIONS CALCULATED ON THE BASIS OF 50 CATIONS PER FORMULA UNIT EXCLUDING THOSE AT THE T1 SITE

\begin{tabular}{lrc}
\hline & $\begin{array}{r}\text { B20761 } \\
\text { Av.core }\end{array}$ & $\begin{array}{c}\text { B20761 } \\
\text { from struct. }\end{array}$ \\
\hline $\mathrm{SiO}_{2}$ & 34.74 & 35.19 \\
$\mathrm{As}_{2} \mathrm{O}_{5}$ & 1.33 & 1.52 \\
$\mathrm{Al}_{2} \mathrm{O}_{3}$ & 11.21 & 11.00 \\
$\mathrm{Mn}_{2} \mathrm{O}_{3}$ & 2.63 & 2.35 \\
$\mathrm{Fe}_{2} \mathrm{O}_{3}$ & 8.04 & 7.96 \\
$\mathrm{MgO}$ & 3.81 & 3.78 \\
$\mathrm{CaO}$ & 35.57 & 34.56 \\
$\mathrm{PbO}$ & & 0.18 \\
$\mathrm{BeO}$ & & 0.67 \\
$\mathrm{~B} \mathrm{O}_{3}$ & & 0.41 \\
$\mathrm{H} \mathrm{O}_{2} \mathrm{O}$ & & 1.27 \\
$\mathrm{~F}$ & & 1.40 \\
$\mathrm{~F}=\mathrm{O}$ & & -0.59 \\
$\mathrm{Total}$ & 97.13 & 99.70 \\
$\mathrm{Ca}$ & 18.96 & 18.98 \\
$\mathrm{~Pb}$ & 0.02 & 0.02 \\
$\mathrm{Al}$ & 6.57 & 6.53 \\
$\mathrm{Fe}$ & 2.99 & 3.017 \\
$\mathrm{Mg}$ & 2.83 & 2.83 \\
$\mathrm{Mn}$ & 0.90 & 0.90 \\
$\mathrm{Si}$ & 17.37 & 17.36 \\
$\mathrm{As}$ & 0.34 & 0.40 \\
$\mathrm{Be}$ & 0.82 & 0.82 \\
$\mathrm{~B}$ & 0.35 & 0.35 \\
$\mathrm{~F}$ & & 2.23 \\
$\mathrm{Charge}$ & 148.88 & 149.081 \\
\hline
\end{tabular}

As at $\mathrm{Z} 2$ require the substitution of $\mathrm{Mg}$ for $\mathrm{Al}$ at $\mathrm{Y} 3$; together, these substitutions require $0.35+0.02+0.32$ $=0.69$ charge deficiency at the Y3 site, close to the 0.83 deficiency indicated by the interpretation of the contents of the $\mathrm{Y} 3$ site given above if $\mathrm{Mn}$ is trivalent, but substantially less than the 1.73 deficiency indicated if $\mathrm{Mn}$ is divalent. Overall, the negative charge total from the structure, including the substitutions discussed above, is 149.46; the positive charge total from the analysis is 148.181 if $\mathrm{Mn}$ is divalent and 149.081 if $\mathrm{Mn}$ is trivalent. Local charge-balance calculations (Brown 1981, Brese \& O'Keeffe 1991) suggest that $\mathrm{Mn}$ is largely trivalent: $\mathrm{Mn}$ at Y3 would receive 3.335 charges from neighboring $\mathrm{O}$ if $\mathrm{Mn}$ is modeled as divalent or 3.076 charges if it is modeled as trivalent. Likewise, $\mathrm{Fe}^{2+}$ would receive 2.867 charges and $\mathrm{Fe}^{3+}$ 
TABLE 10. POSITIVE AND NEGATIVE CHARGEBALANCE COMPARISON FROM DERIVED COMPOSITION OF THE PAJSBERG VESUVIANITE B20761

\begin{tabular}{lcc}
\hline & \# Atoms & Charges \\
\hline $\mathrm{Ca}$ & 18.95 & 37.90 \\
$\mathrm{~Pb}$ & 0.02 & 0.04 \\
$\mathrm{Mg}$ & 2.83 & 5.66 \\
$\mathrm{Al}$ & 6.52 & 19.56 \\
$\mathrm{Fe}^{3+}$ & $2.98(3.017)$ & 9.051 \\
$\mathrm{Mn}^{3+}$ & 0.90 & 2.70 \\
$\mathrm{Si}$ & 17.37 & 69.48 \\
$\mathrm{As}$ & 0.40 & 2.00 \\
$\mathrm{Be}$ & 0.82 & 1.64 \\
$\mathrm{~B}$ & 0.35 & 1.05 \\
$\Sigma-\mathrm{T}$ & 50 & \\
Total positive charges & & 149.081 \\
$68 \mathrm{O}$ bonded to Si & & 136 \\
$1.00 \mathrm{O}$ at O10 & & 2 \\
1.00 OH at O10 & & 1 \\
$2.46 \mathrm{O}$ at O11 & & 4.92 \\
3.31 OH at O11 & & 3.31 \\
$2.23 \mathrm{~F}$ at O11 & & 2.23 \\
Total negative charges & & 149.46 \\
\hline
\end{tabular}

would receive 3.067 charges. Table 10 gives a chargebalance comparison, based on all $\mathrm{Mn}$ and Fe being trivalent; the difference between total anion and total cation charges is $149.46-149.08=0.33$.

The optical absorption spectrum of the Pajsberg vesuvianite appears more compatible with $\mathrm{Mn}$ being trivalent, as do the charge total, overall chargebalance, and charge-balance considerations for Y3 discussed above. We consider $\mathrm{Mn}$ in the Pajsberg vesuvianite to be trivalent. However, the absence of trivalent $\mathrm{Mn}$ at the $\mathrm{Y} 1$ site and the lesser distortion of the Y3 site compared to the vesuvianite from Asbestos, Quebec (Fitzgerald et al. 1986b) favor Mn as divalent. Armbruster \& Gnos (2000) reported a low-temperature, acentric vesuvianite from South Africa containing 14.34 $\mathrm{MnO}$, and posited both $\mathrm{Mn}^{2+}$ and $\mathrm{Mn}^{3+}$ at $\mathrm{Y} 1$ and $\mathrm{Y} 3$ sites. That $\mathrm{Mn}^{3+}$ may be present at $\mathrm{Y} 1$ (Armbruster \& Gnos 2002) or Y3 (this paper), or both (Armbruster \& Gnos 2002) speaks to the crystalchemical complexity of this mineral.

\section{Final note}

In environments which contain sufficient $\mathrm{Be}$ to form some Be mineral, any associated vesuvianite should be expected to contain Be. Beryllium is not detectable by EDS analysis, and it may be more widely present in vesuvianite than currently appreciated. A separate Be-vesuvianite species would require half occupancy of the $\mathrm{Tl}_{4}$ site, or $2 \mathrm{Be}$ in the structural formula. This would require about $2.2 \mathrm{wt} . \% \mathrm{BeO}$ or 0.79 wt.\% Be. Analyses of Franklin vesuvianite reported by Hurlbut (1961) do not exceed this amount and the "beryllium vesuvianite" from Franklin is not a separate species. Further investigation might reveal such a species, however.

\section{ACKNOWLEDGMENTS}

Lee A. Groat and Ulf Halenius provided numerous helpful comments. Funding was provided, in part, by NSF grants EAR 89-16064 and EAR 1322082 to GRR.

\section{REFERENCES}

Armbruster, T. \& GNos, E. (2000) Tetrahedral vaciences and cation ordering in low-temperature vesuvianites. Acta American Mineralogist 85, 570-577.

Armbruster, T. \& Gnos, E. (2002) Tetrahedral vacancies and cation ordering in low-temperature Mn-bearing vesuvianites: Indication of a hydrogarnet-like substitution. American Mineralogist $\mathbf{8 5}, 570-577$.

Armbruster, T., Gnos, E., Dixon, R., Gutzmer, J., Heiny, C., Dobelin, N., \& Medenbach, O. (2002) Manganvesuvianite and tweddillite, two new $\mathrm{Mn}^{3+}$-silicate minerals from the Kalahari manganese fields, South Africa. Mineralogical Magazine 661, 137-150.

Brese, N.E. \& O'KeefFe, M. (1991) Bond valence parameters for solids. Acta Crystallogaphica B47, 192-197.

Brown (1981) The bond-valence method: an empirical approach to chemical structure and bonding. In Structure and Bonding in Crystals II (M. O'Keeffe \& A. Navrotsky, eds.). Academic Press, New York City, New York, United States (1-30).

Bruker (2007) Apex2. Bruker AXS Inc., Madison, Wisconsin, United States.

Dana, E.S. (1893) The System of Mineralogy. John Wiley \& Sons, New York City, New York, United States (p. 481).

Fitzgerald, S.F., Rheingold, A.R., \& Leavens, P.B. (1986a) Crystal structure of a cuprian vesuvianite. American Mineralogist 71, 1011-1014.

Fitzgerald, S.F., Rheingold, A.R., \& Leavens, P.B. (1986b) Crystal structure of a $\mathrm{P} 4 / \mathrm{n}$ vesuvianite. American Mineralogist 71, 1483-1488.

Fitzgerald, S.F., Rheingold, A.R., Leavens, P.B., \& Nelen, J.A. (1987) Crystal structure of a REE-bearing vesuvianite from San Benito County, California. American Mineralogist 72, 625-628.

Fitzgerald, S.F., Leavens, P.B., \& Nelen, J.A. (1992) Chemical variation in vesuvianite. Mineralogy and Petrology 46, 163-178. 
Glass, J.J., Jahns, R.H., \& Stevens R.E. (1944) Helvite and danalite from New Mexico and the helvite group. American Mineralogist 29, 163-191.

Groat, L.A. \& Evans, R.J. (2012) Crystal Chemistry of Biand Mn-bearing vesuvianite from Langbån, Sweden. American Mineralogist 97, 1627-1634.

Groat, L.A. \& Hawthorne, F.C. (1992) The chemistry of vesuvianite. Canadian Mineralogist 30, 19-48.

Groat, L.A., Hawthorne, F.C., \& Ercit, T.S. (1994a) 'Excess' Y-group cations in the crystal structure of vesuvianite. Canadian Mineralogist 32, 497-504.

Groat, L.A., Hawthorne, F.C., \& Ercit, T.S. (1994b) The incorporation of boron into the vesuvianite structure. Canadian Mineralogist 32, 505-523.

Groat, L.A., Evans, R.J., Cempirek, J., McCammon, C., \& HouzAr, S. (2013) Fe-rich and As-bearing vesuvianite and wiluite from Kozlov, Czech Republic. American Mineralogist 98, 1330-1337.

Hurlbut, C.S., JR. (1955) Beryllian idocrase from Franklin, New Jersey. American Mineralogist 40, 118-120

ManNING, P.G. (1968) Optical absorption spectra of octahedrally bonded $\mathrm{Fe}^{3+}$ in vesuvianite. Canadian Journal of Earth Sciences 5, 89-92.

Manning, P.G. \& Tricker, M.J. (1975) Optical-absorption and Mössbauer spectral studies of iron and titanium sitepopulations in vesuvianites. Canadian Mineralogist 13, 259-265.

Mattson, S.M. \& Rossman, G.R. (1987) Identifying characteristics of charge transfer transitions in minerals. Physics and Chemistry of Minerals 14, 94-99.

Meen, V.B. (1939) Vesuvianite from Great Slave Lake region Canada. University of Toronto Studies, Geologic Series 42, 269.

Moore, P.B. (1970) Mineralogy and chemistry of Langbantype deposits in Bergslagen, Sweden. Mineralogical Record 1, 154-172.
Palache, C. (1935) The Minerals of Franklin and Sterling hill, Sussex County, New Jersey. United States Geological Survey Professional Paper 180, $161 \mathrm{pp}$.

Palache, C. \& Bauer, L.H. (1930) On the occurrence of beryllium in the zinc deposits of Franklin, New Jersey. American Mineralogist 15, 30-33.

Platonov, A.N., Zabinski, W., \& Sachabinski, M. (1995) Optical absorption spectra of $\mathrm{Mn}^{3+}$ ions in vesuvianites from Lower Silesia, Poland. European Journal of Mineralogy 7, 1345-1352; Mineralogicheskii Zhurnal 17, 38-47 (in Russian).

PAN, Y. \& FleEt, M.E. (1992) Mineral Chemistry and Geochemistry of vanadian silicates in the Hemlo gold deposit, Ontario, Canada. Contributions to Mineralogy and Pertology 109, 511-525.

Rossman, G.R. (1975) Spectroscopic and magnetic studies of ferric iron hydroxy sulfates: intensification of color in ferric iron clusters bridged by a single hydroxide ion. American Mineralogist 60, 698-704.

Rossman, G.R. (2015) Vesuvianite Visible Spectra. http:// minerals.gps.caltech.edu/FILES/Visible/vesuvianite/ Index.html [date accessed: July 2015]

Rucklidge, J.C., Klockman, V., Whitlow, S.H., \& Gabe, E.J. (1975) The crystal structures of three Canadian vesuvianites. Canadian Mineralogist 13, 15-21.

Sheldrick, G.M. (2008), A short history of SHELX. Acta Crystallographica A64, 112-122, doi: 10.1107/ S0108767307043930

Smith, G., Halenius, U., Annersten, H., \& Ackermann, L. (1983) Optical and Mossbauer spectra of manganesebearing phlogopites: $\mathrm{Fe}^{3+} \mathrm{IV}_{\mathrm{IV}} \mathrm{Mn}^{2+}$ Vi pair absorption as the origin of reverse pleochroism. American Mineralogist 68 , 759-768.

Srivastava, K. \& Mehra, A. (1972) Optical absorption of $\mathrm{NaMnF}_{3}$. Journal of Chemical Physics 57, 1587-1591.

Received April 23, 2015. Revised manuscript accepted May 5, 2016. 